\title{
Effect of Water Ammonia Nitrogen Concentration on Survival of Mosquitofish Gambusia affinis
}

\author{
Jinqing Wang1, Weiguang Lü1, Xiaobin Tao ${ }^{2}$, Hanlin Zhang', Shuangxi Li' ${ }^{1}$, Xianqing Zheng1, \\ Wenzong Zhou ${ }^{*}$ \\ ${ }^{1}$ Eco-Environmental Protection Institute of Shanghai Academy of Agricultural Sciences, Shanghai, China \\ ${ }^{2}$ Shanghai Langbo Ecological Agriculture Technology Co., Ltd, Shanghai, China \\ Email: jinqwang@163.com, ”zhouwz001@163.com
}

Received 10 March 2016; accepted 10 April 2016; published 13 April 2016

Copyright (C) 2016 by authors and Scientific Research Publishing Inc.

This work is licensed under the Creative Commons Attribution International License (CC BY).

http://creativecommons.org/licenses/by/4.0/

c) (i) Open Access

\begin{abstract}
In this study, the relationship of the growth of invasion fish with water eutrophication processes was explored in Yangtze estuary, China. High water ammonia nitrogen concentration produced high effects on the growth and survival of mosquitofish Gambusia affinis. When the ammonia nitrogen was higher than $51.75 \mathrm{mg} / \mathrm{l}$, the fish death rate obviously increased with days, and at the 4th day fish presented the highest mortality, while $23.72 \mathrm{mg} / \mathrm{l}$ ammonia nitrogen conditions have been able to ensure fish survival for two days in experiment treatment. Therefore, ammonia nitrogen of Grade $V$ polluted water (national water quality criteria) is just $3 \mathrm{mg} / \mathrm{l}$, and the water can be enough to support fish normal survival. Our results suggest mosquitofish was a suitable pioneer species for restoring polluted water ecology and purify water.
\end{abstract}

\section{Keywords}

Water Pollution, Ammonia Nitrogen, Mosquitofish, Gambusia affinis, Eutrophication

\section{Introduction}

Eutrophication has become a worldwide environmental problem and has drawn many researchers' attention all over the world. In China, anthropogenic nitrogen contamination and eutrophication in some lakes and rivers have significantly increased due to the rapid development of industry and agriculture over the past several decades. An important characteristic of eutrophication is the breakout of water bloom, followed by dissolved oxygen

${ }^{*}$ Corresponding author.

How to cite this paper: Wang, J.Q., Lü, W.G., Tao, X.B., Zhang, H.L., Li, S.X., Zheng, X.Q. and Zhou, W.Z. (2016) Effect of Water Ammonia Nitrogen Concentration on Survival of Mosquitofish Gambusia affinis. Journal of Water Resource and Protection, 8, 435-437. http://dx.doi.org/10.4236/jwarp.2016.84036 
declining and ammonia increasing. Mosquitofish Gambusia affinis is native to North America and introduced in China in 1927 to control mosquito number. The fish tremendously increased in temperate and tropical regions, and become a serious invasive species today. As a larvivorous fish and prolific breeder, mosquitofish has an negative effect on the ecological function of the lake [1] [2], and their predator behavior could profoundly decrease local biodiversity [3]. When in food shortage, these fish show especially strong cannibalism and predatory behavior on small organisms [4].

Little attention has been paid to the interaction between aquatic biological invasion and water eutrophication. By field investigation, we found that G. affinis was widely distributed in most of the rivers in Fengxian, Shanghai, China. Native species Oryzias latipes in the niche had been completely replaced by mosquitofish, and $O$. latipes is hardly been found in rivers of Fengxian district today. The objective of this study was to determine the effect of water ammonia nitrogen concentration on survival of mosquitofish G. affinis, analyze the relationship between aquatic invasive species and the key index of eutrophication ammonia nitrogen and clarify the tolerance of G. affinis on ammonia toxicity.

\section{Materials and Methods}

We used a dip net to capture the test fish from field river (30 53 '26" - 30 $\left.533^{\prime} 33^{\prime \prime} \mathrm{N}, 121^{\circ} 21^{\prime} 48^{\prime \prime}-121^{\circ} 23^{\prime} 20^{\prime \prime} \mathrm{E}\right)$. Experiments were conducted in laboratory of Shanghai Academy of Agricultural Sciences. Three $1000 \mathrm{ml}$ tanks were deployed for each of control group and four treatments with six fish per tank. G. affinis collected were cultured indoor for one week for their acclimatization to the experimental conditions prior to the formal experiment. In order to reduce water evaporation, tiny airing was used as the mean of water oxygen aeration. Individuals chosen for the experiment were $10 \mathrm{~mm}$ in mean length $( \pm 2 \mathrm{~mm})$. Fish were placed into the tank and fed everyday until the beginning of experiment. During the course of the experiment, we continued observing fish behavior but not feeding them. The numbers of death individuals per tank were recorded at 24, 48, and $96 \mathrm{~h}$ after experiment beginning respectively and then removed dead individuals in time.

\section{Results}

The results show that the mortality rate of mosquitofish increased with the increasing of ammonia nitrogen concentration, and at the $96 \mathrm{~h}$ after experiment beginning, mortality reached the maximum (Table 1). G. affinis could live in the high-ammonia environment compared to the Chinese perch Siniperca chuatsi, and their tolerances on ammonia were different in different growth stages. Yet, excess ammonia nitrogen content also could imperil the survival of $G$. affinis. At the $24 \mathrm{~h}$ of experiment, the fish appeared in the symptoms of the color white. At the $48 \mathrm{~h}$, the fish showed the loss of body balance and the shortness of breath, then their activity slowed down, side tours, roll over, side floating on the water surface. At this time use glass rod to stimulate fish, the fish also can avoid the rod. The death began to appear at the $24 \mathrm{~h}$ and high mortality was found at the $96 \mathrm{~h}$. This result proved that although the G. affinis has high tolerance on ammonia, but excess ammonia concentration still has lethal effect on the fish.

Water pollution and eutrophication have threatened mosquitofish population severely. Excess nutrient concentrations could affect feeding habits and behavior [5], and change mosquitofish body and viability [6], while the volatile ammonia from algae decomposition is especially harmful to fish reproduction, survival and growth [5].

Table 1. Average mortality rates to different ammonia concentrations.

\begin{tabular}{cccc}
\hline \multirow{2}{*}{$\begin{array}{c}\text { Ammonia concentration } \\
(\mathrm{mg} / \mathrm{L})\end{array}$} & \multicolumn{3}{c}{ Average mortality rates (\%) } \\
\cline { 2 - 4 } 0 & $24 \mathrm{~h}$ & $48 \mathrm{~h}$ & $96 \mathrm{~h}$ \\
\hline 23.72 & 0 & 0 & 0 \\
51.75 & 11.1 & 0 & 55.56 \\
71.42 & 16.67 & 16.67 & 77.78 \\
99.63 & 27.78 & 27.78 & 83.33 \\
& 0 & 38.67 & 94.44
\end{tabular}


In short, although G. affinis has considerably high tolerance on ammonia [5] [7], but excess ammonia concentration still has lethal effect on the fish, and mass death of G. affinis appeared after 96 h for exposure to high ammonia. As a widespread invasive species, G. affinis has occupied some ecological niches of native species. The excessive increasing of ammonia produced by water pollution and eutrophication probably inhibits invasion process of mosquitofish.

\section{Conclusion}

At the $4^{\text {th }}$ day of experiment treatment fish showed high mortality rate, and the mortality of experimental fish increased with the increase of ammonia nitrogen concentrations. At the ammonia nitrogen concentration of $23.72 \mathrm{mg} / \mathrm{l}$ mosquitofish can survive two days. Water pollution degree of ammonia nitrogen concentrations has been far inferior to that of national water quality criteria (Grade V, $3 \mathrm{mg} / \mathrm{l}$ ). This result suggested that mosquitofish had high tolerance on water pollution, especially high ammonia, this species can be used as pioneer species, improve the ecology condition of polluted water and purify water quality, conduct ecological restoration on water pollution.

\section{Acknowledgements}

This study was financially supported by China Spark Program (Grant No. 2015GA680005), Shanghai Natural Science Funds (Grant No. 13ZR1427300), Shanghai International Science and Technology Cooperation Projects (Grant No. 14390711800), Science and Technology Development Funds of Shanghai Academy of Agricultural Sciences (Grant No. YF2012 (12)), Science and Technology Develop Agriculture Funds (Grant No. TG04) and Shanghai 2015 Chongming agricultural field Tech-Aid funds (Grant No. 15391912200).

\section{References}

[1] Becker, A., Laurenson, L.J.B., Jones, P.L. and Newman, D.M. (2005) Competitive Interactions between the Australian Native Fish Galaxias maculatus and the Exotic Mosquito Fish Gambusia holbrooki, in a Series of Laboratory Experiments. Hydrobiologia, 549, 187-196. http://dx.doi.org/10.1007/s10750-005-6425-y

[2] Nagdali, S.S. and Gupta, P.K. (2002) Impact of Mass Mortality of a Mosquito Fish, Gambusia affinis on the Ecology of a Fresh Water Eutrophic Lake (Lake Naini Tal, India). Hydrobiologia, 468, 45-51. http://dx.doi.org/10.1023/A:1015270206187

[3] Hurlbert, S.H., Zedler, J. and Fairbanks, D. (1972) Ecosystem Alteration by Mosquito Fish (Gambusia affinis) Predation. Science, 175, 639-641. http://dx.doi.org/10.1126/science.175.4022.639

[4] Dionne, M. (1985) Cannibalism, Food Availability, and Reproduction in the Mosquito Fish (Gambusia affinis): A Laboratory Experiment. American Naturalist, 126, 16-23. http://dx.doi.org/10.1086/284392

[5] Staub, B.P., Hopkins, W.A., Novak, J. and Congdon, J.D. (2004) Respiratory and Reproductive Characteristics of Eastern Mosquitofish (Gambusia holbrooki) Inhabiting a Coal Ash Settling Basin. Archives of Environmental Contamination and Toxicology, 46, 96-101. http://dx.doi.org/10.1007/s00244-003-0240-0

[6] Edwards, T.M. and Guillette, L.J. (2007) Reproductive Characteristics of Male Mosquitofish (Gambusia holbrooki) from Nitrate-Contaminated Springs in Florida. Aquatic Toxicology, 85, 40-47. http://dx.doi.org/10.1016/j.aquatox.2007.07.014

[7] Blanco, S., Romo, S. and Villena, M.J. (2004) Experimental Study on the Diet of Mosquitofish (Gambusia holbrooki) under Different Ecological Conditions in a Shallow Lake. International Review of Hydrobiology, 89, 250-262. http://dx.doi.org/10.1002/iroh.200310684 